\title{
Ternary diagram of extract proteins / solvent systems: Sesame, soybean and lupine proteins
}

\author{
By M. A. Khedr ${ }^{1}$ and S.S. Mohamed ${ }^{2}$
}

\author{
${ }^{1}$ Chem. Eng. \& Pilot Plant Dept. \\ ${ }^{2}$ Fats \& Oils Dept. \\ National Research Center, Dokki, Cairo, Egypt.
}

\section{RESUMEN}

Diagrama ternario de sistemas de extracción proteínas/disolvente: Proteínas de sésamo, soja y altramuz.

La extracción con disolventes es un método de extracción de proteínas de las harinas de semillas oleaginosas que ofrece la ventaja de su elevada eficacia. Desafortunadamente, la bibliografía coincide en el vacío existente con respecto a los diagramas de equilibrio necesarios para el diseño de los equipos adecuados.

Debido a esta falta de conocimientos, el presente estudio se ha llevado a cabo para obtener datos de tres sistemas ternarios: sistema proteína de sésamo / disolución de hidróxido sódico, sistema proteína de soja / disolución de hidróxido sódico y sistema proteína de altramuz / disolución de hidróxido sódico. Dichas harinas de semillas oleaginosas se seleccionaron por su alto contenido en proteínas $(53,4 \%, 46,2 \%$ y $42,3 \%$, respectivamente).

El estudio también contempló la evaluación de los parámetros más importantes que afectan al proceso de extracción, es decir, la normalidad de la disolución de hidróxido sódico utilizada como agente de extracción y la relación inicial disolvente: harina. Los resultados obtenidos indican que la mejor normalidad de la disolución de hidróxido sódico usada para extraer la proteína de la harina de soja y altramuz es $0,02 \mathrm{~N}$ mientras que para la de sésamo es $0,04 \mathrm{~N}$. Asimismo operando con una relación líquido/sólido de 30:1 y 50:1 para soja y sésamo o altramuz respectivamente, se consiguen extractos con alto contenido en proteínas. Se han obtenido correlaciones gráficamente para diferentes puntos del sistema, y los datos se han comprobado con los calculados analíticamente.

PALABRAS-CLAVE: Altramuz - Datos de equilibrio - Extracción de proteínas - Sésamo - Soja.

\section{SUMMARY}

Ternary diagram of extract proteins / solvent systems: Sesame, soybean and lupine proteins.

Solvent extraction as a method of extracting protein from oilseed meals offers the advantage of higher efficiency. Unfortunately, the published literature points to the gap in the work concerned with the necessary equilibrium diagram to design due process equipment for such extracts.

Initiated by this lack of basic knowledge, the present study has been undertaken to provide the equilibrium data for three different ternary systems, namely: sesame protein / sodium hydroxide solution system, soybean protein / sodium hydroxide solution system and lupine protein / sodium hydroxide solution system. These oilseed meals were selected because of their high protein content $(53.4 \%, 46.2 \%$ and $42.3 \%$ protein, respectively).

The study also concentrated on the evaluation of the major parameters affecting the extraction process, i.e. the normality of the sodium hydroxide solution used as extracting solvent and the initial oilseed solvent to meal feeding ratio. The results obtained indicate that the best normality of sodium hydroxide solution used for extracting soybean and lupine protein is $0.02 \mathrm{~N}$, while $0.04 \mathrm{~N}$ solution is required for extracting sesame protein. Also, operating at a liquid to solid feed ratio of 30:1 and 50:1 for soybean, sesame and lupine, respectively, is enough to reach a high protein extract. Correlations were presented for each locus of under flow compositions, graphically acquired, and the data are compared with those calculated by analytical solutions.

KEY-WORDS: Equilibrium data - Lupine - Protein extraction - Sesame - Soybean.

\section{INTRODUCTION}

Oilseed proteins rank high among the unconventional sources of protein proposed by the Protein Advisory Group of the United Nations (1968) to bridge the protein gap in developing countries.

Oilseeds in general, after the extraction of the oil, yield a product known as meal, which is considerably rich in protein. Several protein products have been prepared and are already in the world market. These products include flours, protein concentrates, protein isolates, textured proteins, protein hydrolysates and others.

For effective utilization of meal protein, the protein has to be solubilized, extracted (leached) out of the meal. Several solvents have been investigated for the extraction of the protein from the meal (Abbasy et al., 1981; Taha et al., 1981, 1987). The use of sodium hydroxide of normalities ranging between 0.02 and $0.2 \mathrm{~N}$ has been recommended by Berardi et al., 1969; Fan \& Sosulski, 1974; Abbasy et al., 1981; Taha et al., 1981, 1986, 1987. Although, other factors- such as the solvent to meal ratio, temperature, contact time and particle-size play an important role during the extraction of the protein from the meal, yet the separation of soluble matter from its mixture with insoluble solid depends primarily on the equilibrium distribution of the solute between the miscella and the leached residue. Knowledge of these distribution relationships is essential for a common process design as well as for selecting the ratio of extraction solvent to feed that enters an existing extraction battery and for evaluating the mass transfer rates or theoretical stage efficiencies achieved in process equipment. 
The present work aims at covering the lack of phase equilibrium data of protein extraction (leaching) process from oilseed meal protein, namely, soybean, sesame and lupine meal through sodium hydroxide solution as solvent. This will be achieved first through the determination of the most appropriate operating parameters for the leaching process, namely, the normality of sodium hydroxide and the solvent to meal ratio. The latter set will then provide experimental measurements of the amounts and compositions of thickened solids (under flow phase) and corresponding solution (overflow phase) after long contact time, which are required as a datum that enables the establishment of equilibrium conditions.

\subsection{Theoretical Background}

The quantitative treatment for a solid- liquid extraction system is usually based on the material balances and the ideal-stage concept.

The ternary system involving pure solvent $(S)$, insoluble carrier solid (B) and soluble solute (A), at constant temperature, may be represented on either an equilateral or right triangular diagram (Badger and Banchero, 1955; Mecabe et al., 1993). Figure 1 demonstrates an expanded section of the triangular diagram illustrating the general treatment applied to a specific leaching case.

The composition of the solid-feed stream is shown on the diagram by point $\left(\chi_{0}\right)$, as it is a solvent-free mixture, while that of the solvent is represented on the diagram by point $\left(\mathrm{Y}_{2}\right)$ for pure component. The hypotenuse illustrates the locus of all overflow compositions if no solid is entrained with the liquid phase stream.

The total mass balance for the system is represented by:

$$
M=L_{0}+V_{2}=L_{1}+V_{1}
$$

Solute and solvent mass balances give the following equations respectively:

$$
\begin{aligned}
& M\left(\chi_{A}\right)_{M}=L_{0}\left(\chi_{A}\right)_{0}+V_{2}\left(Y_{A}\right)_{2}=L_{1}\left(\chi_{A}\right)_{1}+V_{1}\left(Y_{A}\right)_{1}(2) \\
& M\left(\chi_{S}\right)_{M}=L_{0}\left(\chi_{S}\right)_{2}+V_{2}\left(Y_{S}\right)_{2}=L_{1}\left(\chi_{S}\right)_{1}+V_{1}\left(Y_{S}\right)_{1}(3)
\end{aligned}
$$

By its definition, point $\left(\chi_{M}\right)$ - whose coordinates are $\left\{\left(\chi_{A}\right)_{M},\left(\chi_{S}\right)_{M}\right\}$ on the diagram must lie on the initial condition line through points $\left(\chi_{0}\right)$ and $\left(Y_{2}\right)$ at such a location that:

$$
\frac{\left(\chi_{\mathrm{A}}\right)_{M}-\left(\chi_{\mathrm{A}}\right)_{o}}{\left(\mathrm{Y}_{\mathrm{A}}\right)_{2}-\left(\chi_{\mathrm{A}}\right)_{M}}=\frac{\left(\chi_{S}\right)_{M}-\left(\chi_{S}\right)_{o}}{\left(\mathrm{Y}_{S}\right)_{2}-\left(\chi_{S}\right)_{M}}=\frac{V_{2}}{L_{o}}
$$

According to equations (1-3), the point $\left(\chi_{M}\right)$ must also lie on the operating line joining points $\left(\chi_{1}\right)$ and
$\left(Y_{1}\right)$, where these points represent the composition of the underflow and the overflow streams, respectively. Furthermore, with the assumption that component (A) is completely dissolved-due to sufficient contact time and agitation- and with the application of the ideal stage concept, the underflow stream $\left(L_{1}\right)$ may be considered to consist of a mixture of components (B), represented by the origin, and a solution of composition represented by point $\left(\mathrm{Y}_{1}\right)$. It follows from the above reasoning that the origin and points $\left(\chi_{1}\right),\left(\chi_{M}\right)$ and $\left(Y_{1}\right)$ must also lie on the same straight line. This fact is utilized to locate point $\left(\mathrm{Y}_{1}\right)$ by determining the intersection of the line joining the origin, and point $\left(\chi_{M}\right)$ with the locus of overflow streams, i.e., the hypotenuse. Subsequently, point $\left(\chi_{1}\right)$ can be situated on that line providing data are available on the amount of solution retained in the solid phase, according to the following relationships (Badger and Banchero, 1955):

$$
\frac{\text { Mass of solution retained }}{\text { Mass of underflow stream }}=\frac{\chi_{A}}{Y_{A}}=\frac{\chi_{S}}{Y_{S}}
$$

By solving equation (5) for either $\left(\chi_{A}\right)$ or $\left(\chi_{s}\right)$.

By repeating the above procedure for other solid feed liquid mixtures, the underflow equilibrium line is generated.

\section{MATERIALS AND METHODS}

\subsection{Material}

Soybean (Glycine max), sesame seed (Sesanum indicum) and lupine (Lupinus albus) were supplied by the Ministry of Agriculture, Giza, Egypt.

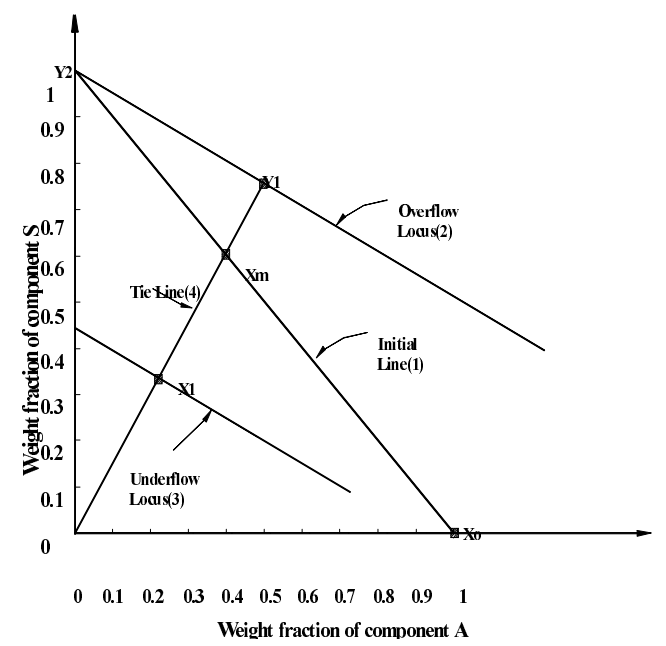

Figure 1

Expanded section of the triangular diagram for general treatment applied to a specific case. 


\subsection{Preparation of Oilseed Meals}

Sesame, soybean, and lupine were dehulled and ground. The oil was extracted with $n$-hexane using a soxhlet apparatus. After 24 hours, the meals were reground then extracted with freshs solvent for another 24 hours. The meal was spread to dry at room temperature, then ground to pass an 80 mesh screen.

\subsection{Chemical Analysis of the meals}

The three meals used were analyzed for moisture, residual oil, protein, ash and fiber according to AOCS methods of analysis (AOCS, 1998), nitrogen free extract was calculated by difference.

\subsection{Meal protein extraction}

The experiments carried out for the extraction of meal protein from the three seed meals were designed according to the previously mentioned theoretical background to fulfill the quantitative requirements for equilibrium data calculation.

\subsubsection{Normality study}

The basic experiments for the determination of the normality of sodium hydroxide, which will ensure maximum solubilization of the meal protein was accomplished according to Lyman et al. (1953).

$1 \mathrm{~g}$ meal and $10 \mathrm{~g}$ glass beads ( $2 \mathrm{~mm}$ diameter) were placed into $250 \mathrm{ml}$ Erlenmeyer flasks. The sodium hydroxide solution was added in a solvent to meal ratio of 10:1. Extraction was carried out at room temperature for 90 minutes. The mixtures were then centrifuged at $5000 \mathrm{xg}$ for 10 minutes. One-milliliter aliquots of the supernatant solutions were taken for nitrogen determination. Percent dissolution was calculated according to the actual recovery of solvent.

Table I

Chemical composition of soybean, sesame and lupine seed meals*

\begin{tabular}{|l|c|c|c|c|c|}
\hline \multicolumn{1}{|c|}{ Meals } & Protein & Oil & Ash & Fiber & NFE \\
& $\%$ & $\%$ & $\%$ & $\%$ & $\%$ \\
\hline Soybean & $46.2 \pm 0.02$ & $0.09 \pm 0.1$ & $7.2 \pm 0.8$ & $5.5 \pm 0.6$ & 41.0 \\
Sesame & $53.4 \pm 0.01$ & $0.8 \pm 0.1$ & $3.2 \pm 0.3$ & $3.0 \pm 0.4$ & 39.6 \\
Lupine & $42.3 \pm 0.02$ & $0.04 \pm 0.3$ & $2.7 \pm 0.5$ & $14.7 \pm 0.3$ & 39.9 \\
\hline
\end{tabular}

${ }^{*}$ values are given on moisture- free basis.

Table II

Solubility of soybean, sesame and lupine seed meal protein using different normalities of sodium hydroxide solutions*

\begin{tabular}{|c|c|c|c|}
\hline \multirow{2}{*}{ Normality of NaOH } & \multicolumn{3}{|c|}{ \% protein extracted } \\
\cline { 2 - 4 } & Soybean & Sesame & Lupine \\
\hline 0.01 & $96.2 \pm 0.04$ & $84.8 \pm 0.03$ & $65.3 \pm 0.05$ \\
0.02 & $98.2 \pm 0.06$ & $86.4 \pm 0.03$ & $85.2 \pm 0.01$ \\
0.03 & $95.7 \pm 0.05$ & $87.1 \pm 0.05$ & $78.1 \pm 0.02$ \\
0.04 & $93.3 \pm 0.03$ & $89.6 \pm 0.08$ & $75.0 \pm 0.05$ \\
0.5 & $93.0 \pm 0.04$ & $86.0 \pm 0.02$ & $68.6 \pm 0.03$ \\
0.06 & $92.1 \pm 0.02$ & $85.7 \pm 0.06$ & $62.9 \pm 0.04$ \\
\hline
\end{tabular}

${ }^{*}$ Calculations are based on the actual recovery of solvent. 


\subsubsection{Solvent to meal ratio study}

After the elucidation of the optimum normality of sodium hydroxide for the extraction of protein from each meal individually, the solvent: meal ratios were investigated. The same procedure as in 4.1 was carried out; only the shaking was carried out for $4 \mathrm{hrs}$. Then the flasks with their contents were left overnight. After centrifugation the volume of supernatant was recorded and the precipitate was weighed. In this experiment the extracted protein percentage was calculated on the basis of the actual recovery of solvent.

\section{RESULTS AND DISCUSSION}

\subsection{Experimental Results}

Table I gives the chemical composition of soybean, sesame and lupine seed meals. It is clear that the three meals are rich sources of proteins. The protein content ranges from 42 to $53 \%$. Table II shows the solubility of the three investigated meal protein when using sodium hydroxide with different normalities. Results in the table indicate that $0.02 \mathrm{~N}$ sodium hydroxide solution extracted the highest protein percent from both soybean and lupine meals, accomplishing 98.2 and $85.2 \%$ protein extraction, respectively. As for the solubilization of sesame seed meal protein, $0.04 \mathrm{~N}$ sodium hydroxide resulted in the highest protein extraction reaching $89.6 \%$.

Results of the investigation of the effect of the solvent to meal ratios on the extractability of the three meal proteins are represented in Table III. It indicates that the highest percent protein extracted from soybean meal and sesame meal was achieved at a solvent: meal of $30: 1(\mathrm{v} / \mathrm{w})$ resulting in $99.3 \%$ and $90.0 \%$ protein extracted, respectively. On the other

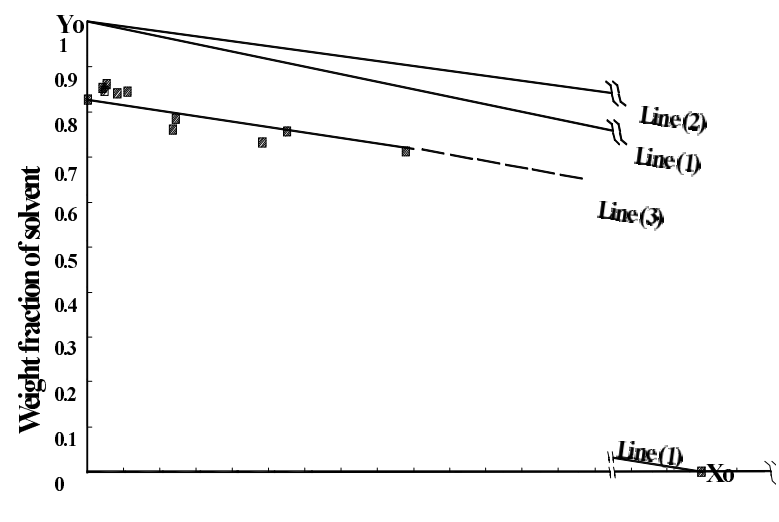

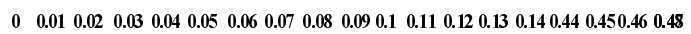

Figure 2

Expanded triangular diagram for protein extract from soya-sodium hydroxide solution system. hand, a 50:1 solvent to meal ratio extracted the highest protein from lupine meal reaching $98.76 \%$. Taha et al. $(1986,1987)$ had investigated solvent to meal ratios of 50:1 and 100:1 with an extraction time of $30 \mathrm{~min}$ and at a temperature of $30^{\circ} \mathrm{C}$ and found the highest protein extraction to take place at 100:1 ratio $(\mathrm{v} / \mathrm{w})$ and to reach $98.2,85.2$ and $89.6 \%$ for soybean, lupine and sesame, respectively. Although $30: 1$ and $50: 1$ are rather high solvent to meal ratios, they are the result of a single step extraction performed in this study. In the industry such high ratios would cause problems, but since they use mostly countercurrent extraction processes and not single extractions they can use much lower solvent to meal ratios.

\subsection{Equilibrium Results}

The experimental data derived from Tables I and II on the extraction of protein from soybean, sesame and lupine meals at room temperature, constant time and different liquid / solid ratios are shown in Tables IV to VI for each meal respectively. The three tables also illustrate the corresponding calculated results of the coordinates of points on the locus of underflow compositions.

Inspection of the data obtained for these particular cases reveals that the variation in the amount of solution retained per unit weight of protein- free meal (P) is relatively small. Consequently, the locus of underflow compositions shows a linear relationship as observed in the graphical representations of the ternary diagram corresponding to the three systems respectively (Figure 2 to Figure 4).

By using the least-square method, the following equilibrium relationships are deduced:

$$
Y_{A}=1.25 \chi_{A} \quad \text { for soybean system }
$$

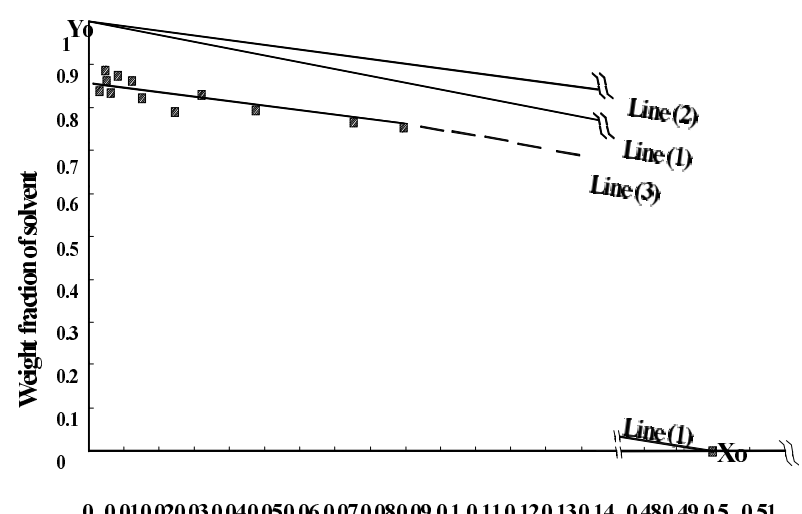

Weight fraction of protein

Figure 3

Expanded triangular diagram for protein extract from sesame-sodium hydroxide system. 


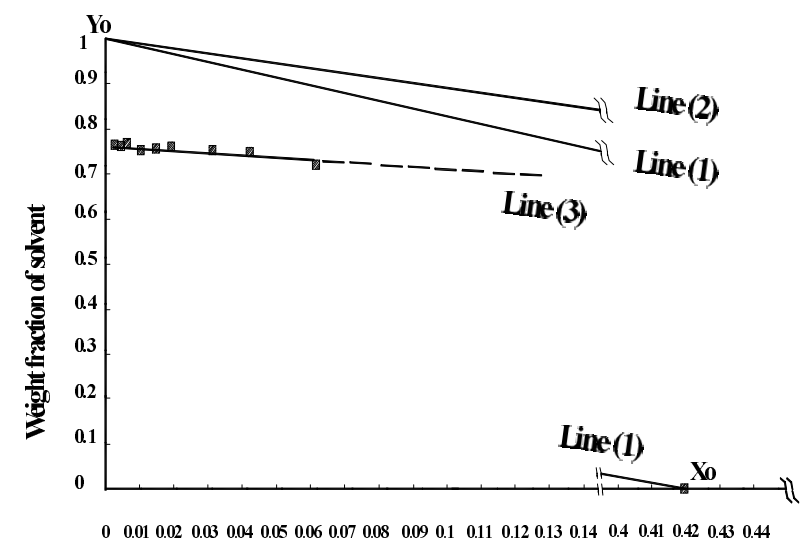

Weight fraction of protein

Figure 4

Expanded triangular diagram for protein extract from lupine-sodium hydroxide solution system.

$Y_{A}=1.18 \chi_{A} \quad$ for sesame system

$Y_{A}=1.31 \chi_{A} \quad$ for lupine system

These results illustrate the equilibrium behavior of these systems, exhibiting cases where preferential adsorption of the protein solute distributes unequally between overflow and underflow phases at equilibrium.

\subsection{Reliability of Equilibrium Diagram Data}

Finding reliable equilibrium data is the most important task involved in developing a reliable design for leaching systems. Therefore, this section aims at investigating the consistency and reliability of experimental results. For this purpose, a computer program simulating the stepwise graphical procedure is developed according to the flow chart shown in Figure 5.

Iterative calculations are conducted to determine the equilibrium diagram data at various liquid / solid ratios $(R)$, taking into account the average estimate of solution retained in the undisolved solids.

The results obtained by both analytical and graphical solutions for the three systems under study are shown in Table VII. The table depicts the relationships governing the ternary equilibrium diagrams in terms of mixture compositions with respect to various ratios of solvent to meal. The derivations of these equations are computed by regression analysis yielding a correlation factor $(r)$ ranging from $94 \%$ to $97 \%$.

The above correlations demonstrate a good agreement between the corresponding data obtained graphically and analytically. This proves the satisfactory accuracy of the reported equilibrium data, necessary to design protein extractors.

It is worth noting that the amount of the solution retained per unit weight of inert solid can be estimated directly from the computed values of the

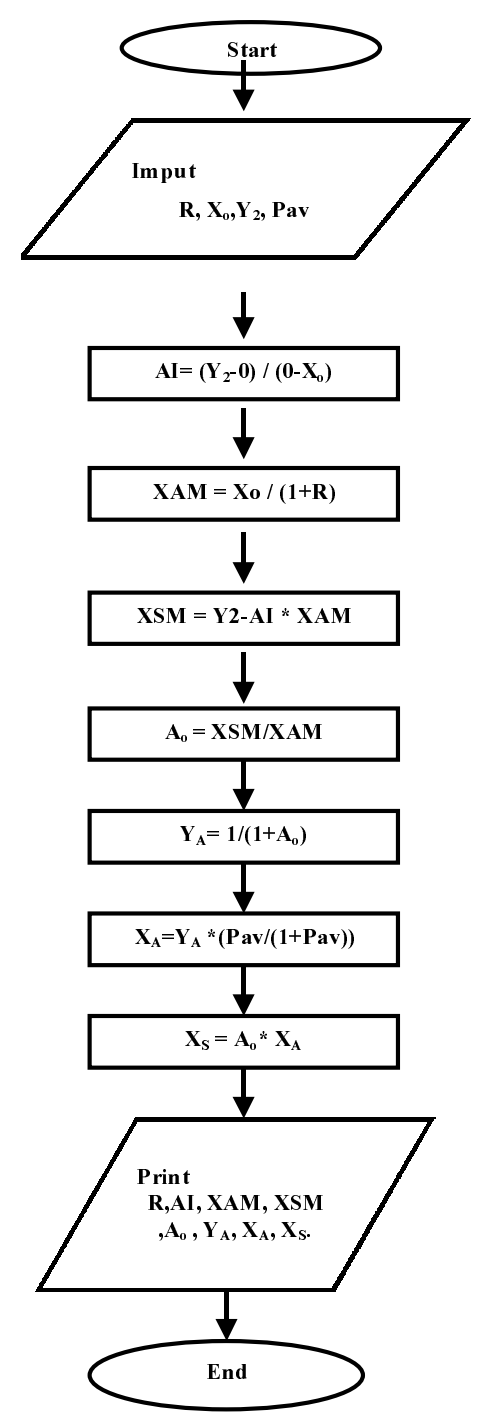

Figure 5

Flow chart of the developed computer program for the determination of equilibrium data.

intersection of the underflow compositions line with the vertical axis, represented by the above equations.

\section{CONCLUSIONS}

The modern processing of some oilseeds yields highly nutritive protein meals, either to be marketed as animal feeds or used as protein extracts which are of interest to many food industries (biscuits, flours, blends, pasta, etc.). It is, therefore, useful to have information on the equilibrium diagram necessary for extractor designs for such extracts.

The obtained equilibrium data for the three highly ranked oilseed protein meals, under investigation, provides the specifications of all design parameters governing either a newly protein meal extraction plant or a specific existing extractor. 
Table III

Percent protein extracted from soybean sesame and lupine seed meals using $0.02 \mathrm{~N}$ and $0.04 \mathrm{~N}$ sodium hydroxide solutions at different solvent to meal ratios ${ }^{\star}$

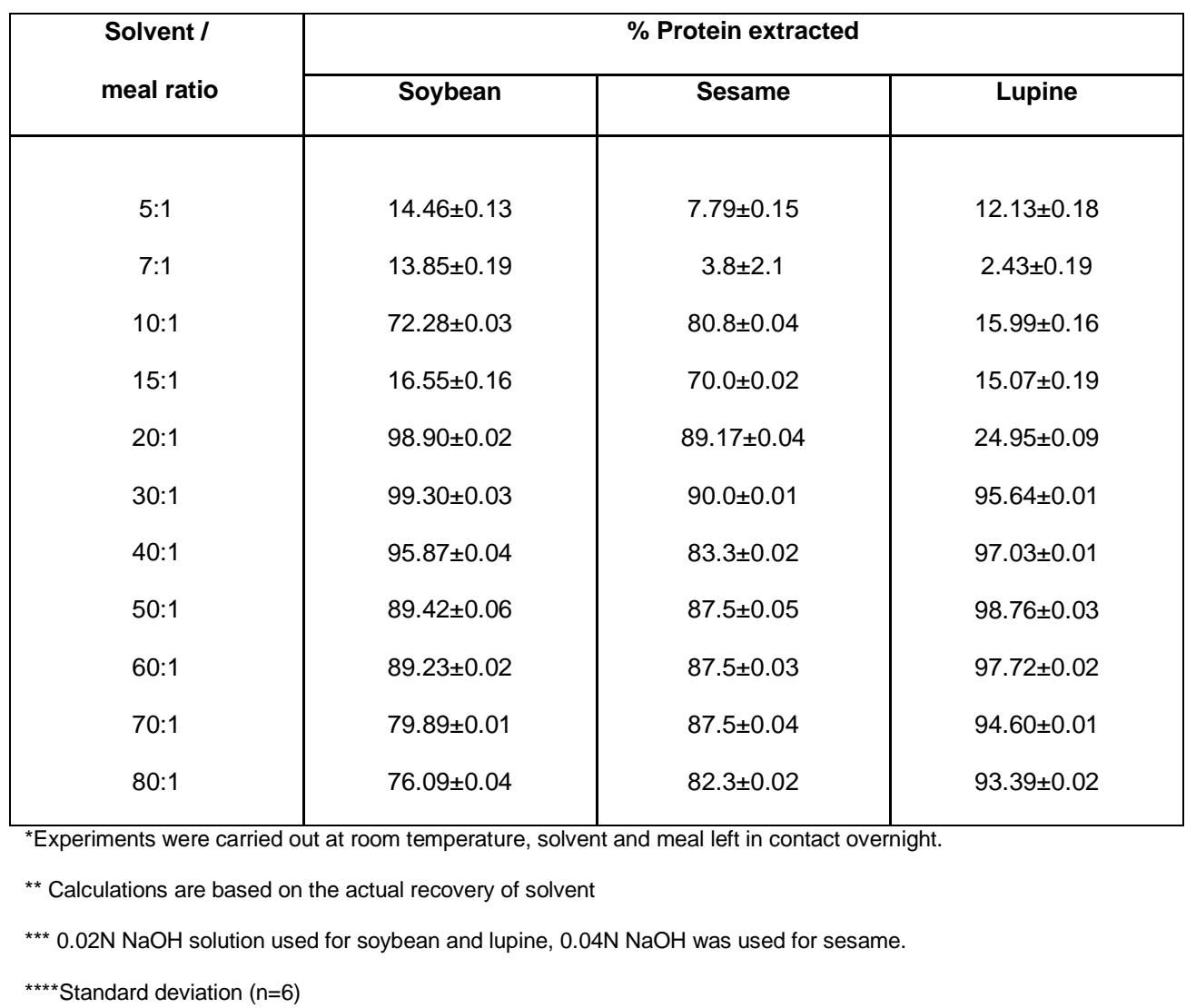

Table IV

Experimental and calculated equilibrium data for protein extraction from soybean meal

\begin{tabular}{|c|c|c|c|c|c|c|}
\hline \multicolumn{2}{|c|}{ Experimental data } & \multicolumn{5}{c|}{ Underflow compositions } \\
\hline Solution comp. & Solution retained comp. & \multicolumn{2}{|c|}{ Per gm. of protein-free meal } & \multicolumn{2}{c|}{ Weight fractions } \\
\cline { 2 - 6 }$\left(y_{A}\right)$ & $(\mathrm{P})$ & gm. of & gm. of & gm. of under- & & $\left(\chi_{s}\right)$ \\
gm. Protein / & gm. Solution retained / & protein & solvent & flow stream & $\left(\chi_{A}\right)$ & \\
gm. Overflow stream. & gm. protein free meal & $(\mathrm{A})$ & $(\mathrm{S})$ & & & \\
\hline 01085 & 4.1153 & 0.4465 & 3.6688 & 5.1153 & 0.0873 & 0.7172 \\
0.0675 & 4.1923 & 0.2830 & 3.9093 & 5.1923 & 0.0545 & 0.7530 \\
0.0631 & 3.7444 & 0.2363 & 3.5081 & 4.7444 & 0.0498 & 0.7394 \\
0.0293 & 4.330 & 0.1269 & 4.2031 & 5.330 & 0.0238 & 0.7885 \\
0.0304 & 13.482 & 0.1059 & 3.376 & 4.482 & 0.0236 & 0.7532 \\
0.0183 & 4.224 & 0.0773 & 4.1467 & 5.224 & 0.0148 & 0.7938 \\
0.0095 & 5.313 & 0.0505 & 5.2625 & 6.313 & 0.008 & 0.8336 \\
\hline
\end{tabular}


Table V

Experimental and calculated equilibrium data for protein extraction from sesame meal

\begin{tabular}{|c|c|c|c|c|c|c|}
\hline \multicolumn{2}{|c|}{ Experimental data } & \multicolumn{5}{|c|}{ Underflow compositions } \\
\hline \multirow{2}{*}{$\begin{array}{c}\text { Solution comp. } \\
\left(Y_{A}\right) \\
\text { gm. Protein / } \\
\text { gm. Overflow stream. }\end{array}$} & \multirow{2}{*}{$\begin{array}{l}\text { Solution retained comp. } \\
\qquad(\mathrm{P}) \\
\text { gm. Solution retained/ } \\
\text { gm. protein. free meal }\end{array}$} & \multicolumn{3}{|c|}{ Per gm. Of protein-free meal } & \multicolumn{2}{|c|}{ Weight fractions } \\
\hline & & $\begin{array}{l}\text { gm. of } \\
\text { protein } \\
\text { (A) }\end{array}$ & $\begin{array}{l}\text { gm. of } \\
\text { Solvent } \\
\text { (S) }\end{array}$ & $\begin{array}{l}\text { gm. of under- } \\
\text { flow stream }\end{array}$ & $\left(\chi_{A}\right)$ & $\left(\chi_{s}\right)$ \\
\hline 0.1034 & 5.67 & 0.5863 & 5.084 & 6.67 & 0.0878 & 0.7622 \\
\hline 0.0880 & 5.664 & 0.4984 & 5.1656 & 6.664 & 0.0748 & 0.775 \\
\hline 0.0589 & 4.944 & 0.2918 & 4.652 & 5.944 & 0.049 & 0.782 \\
\hline 0.0377 & 5.662 & 0.2135 & 5.4485 & 6.662 & 0.032 & 0.8178 \\
\hline 0.0276 & 4.597 & 0.1268 & 4.4702 & 5.597 & 0.0227 & 0.7986 \\
\hline 0.0174 & 4.940 & 0.0859 & 4.8537 & 5.94 & 0.0145 & 0.8172 \\
\hline 0.0133 & 6.377 & 0.0847 & 6.2864 & 7.377 & 0.0115 & 0.8528 \\
\hline 0.0108 & 7.062 & 0.0763 & 6.9857 & 8.062 & 0.0095 & 0.8665 \\
\hline 0.0086 & 4.72 & 0.0428 & 4.929 & 5.972 & 0.0072 & 0.8254 \\
\hline 0.0071 & 4.926 & 0.0350 & 4.891 & 5.926 & 0.0059 & 0.8253 \\
\hline 0.0063 & 7.39 & 0.0311 & 4.908 & 5.939 & 0.0052 & 0.8264 \\
\hline
\end{tabular}

Table VI

Experimental and calculated equilibrium data for protein extraction from lupine meal

\begin{tabular}{|c|c|c|c|c|c|c|}
\hline \multicolumn{2}{|c|}{ Experimental data } & \multicolumn{5}{|c|}{ Underflow compositions } \\
\hline Solution comp & Solution retained comp. & \multicolumn{3}{|c|}{ Per gm. Of protein-free meal } & \multicolumn{2}{c|}{ Weight fractions } \\
\cline { 3 - 7 }$\left(\mathrm{y}_{\mathrm{A}}\right)$ & $(\mathrm{P})$ & gm. of & gm. of & gm. of under- & & \\
gm. Protein / & gm. Solution retained / & protein & Solvent & flow stream & $\left(\chi_{A}\right)$ & $\left(\chi_{S}\right)$ \\
gm. Overflow stream. & gm. protein. free meal & $(\mathrm{A})$ & $(\mathrm{S})$ & & & \\
\hline 0.078 & 3.432 & 0.2677 & 3.164 & 4.432 & 0.0604 & 0.7139 \\
0.0562 & 3.426 & 0.1925 & 3.2334 & 4.426 & 0.0435 & 0.7305 \\
0.0421 & 3.31 & 0.01394 & 3.1706 & 4.310 & 0.0323 & 0.7356 \\
0.0233 & 3.40 & 0.0792 & 3.3208 & 4.40 & 0.018 & 0.7547 \\
0.0203 & 3.31 & 0.0672 & 3.243 & 4.31 & 0.0156 & 0.7524 \\
0.0125 & 3.17 & 0.0396 & 3.1304 & 4.17 & 0.0095 & 0.7507 \\
0.0067 & 3.1543 & 0.024 & 3.1303 & 4.1543 & 0.0058 & 0.7535 \\
0.0065 & 3.445 & 0.0224 & 3.4226 & 4.445 & 0.005 & 0.768 \\
0.0055 & 3.583 & 0.0197 & 3.5633 & 4.583 & 0.0043 & 0.776 \\
0.0047 & 3.303 & 0.0155 & 3.2875 & 4.303 & 0.0036 & 0.764 \\
\hline
\end{tabular}


Tabla VII

Comparison between executed and graphical results

\begin{tabular}{|c|c|c|c|c|c|c|}
\hline System & \multicolumn{2}{|c|}{ Soybean } & \multicolumn{2}{|c|}{ Sesame } & \multicolumn{2}{|c|}{ Lupine } \\
\hline Line equation & Executed Results & Graphical Results & Executed Results & Graphical Results & Executed Results & Graphical Results \\
\hline Initial condition line & $\chi_{s}=1-2.174 \chi_{A}$ & $\chi_{s}=1-2.174 \chi_{A}$ & $\chi_{s}=1-1.982 \chi_{A}$ & $\chi_{s}=1-1.982 \chi_{A}$ & $\chi_{s}=1-2.38 \chi_{A}$ & $\chi_{S}=1-2.38 \chi_{A}$ \\
\hline Locus of underflow & $\chi_{s}=0.82-0.97 \chi_{A}$ & $\chi_{\mathrm{S}}=0.84-1.58 \chi_{\mathrm{A}}$ & $\chi_{\mathrm{s}}=0.84-1.013 \chi_{\mathrm{A}}$ & $\chi_{\mathrm{s}}=0.841-0.934 \chi_{\mathrm{A}}$ & $\chi_{S}=0.77-0.99 \chi_{A}$ & $\chi_{\mathrm{s}}=0.767-0.90 \chi_{\mathrm{A}}$ \\
\hline Operating line & $\chi_{S}=2.17 R^{0.99} \chi_{A}$ & $\chi_{\mathrm{S}}=1.56 \mathrm{R}^{1.05} \chi_{\mathrm{A}}$ & $\chi_{\mathrm{s}}=1.98 \mathrm{R} \chi_{\mathrm{A}}$ & $\chi_{s}=1.603 R^{1.05} \chi_{A}$ & $\chi_{s}=2.378 R \chi_{A}$ & $\chi_{s}=2.243 R^{1.04} \chi_{A}$ \\
\hline Equilibrium line & $O_{A}=1.21 \dot{\mathrm{A}}_{\mathrm{A}}$ & $\mathrm{O}_{A}=1.25 \div \mathrm{*}$ & $O_{A}=1.19 \div A$ & $\mathrm{O}_{A}=1.18 \doteqdot_{\mathrm{A}}$ & $O_{A}=1.30 \dot{\div}_{A}$ & $O_{A}^{\prime}=1.31 \dot{\div}_{A}$ \\
\hline
\end{tabular}




\section{Nomenclature}

$\mathrm{Al}=$ Slope of initial condition line equation.

$\mathrm{AO}=$ Slope of tie line equation.

$L=$ Solid mass, $\left(L_{0}\right)$ for inlet feed, $\left(L_{1}\right)$ for outlet underflow, $(\mathrm{Kg} / \mathrm{hr})$.

$M=$ Mass of overall mixture, $(\mathrm{Kg} / \mathrm{hr})$.

$\mathrm{P}=$ Retained solution in underflow, gm solution/gm solute-free meal.

$\mathrm{R}=$ Liquid to solid ratio.

$\mathrm{V}=$ Mass of solvent, $\mathrm{V}_{2}$ for inlet stream, $\mathrm{V}_{1}$ for overflow stream, $(\mathrm{Kg} / \mathrm{hr})$.

$X=$ Mass fraction in solid phase, $\left(\chi_{A}\right)$ for solute. $\left(\chi_{s}\right)$ for solvent.

$\mathrm{Y}=$ Mass fraction in solvent phase, $\left(\mathrm{Y}_{\mathrm{A}}\right)$ for solute, $\left(\mathrm{Y}_{\mathrm{S}}\right)$ for solvent.

\section{REFERENCES}

Abbasy M., Taha F.S., Hamouda A.A. 1981. A Protein isolate by countercurrent extraction and isoelectric precipitation of peanuts. Grasas y Aceites 32, 171-175.

AOCS 1998. "Official methods recommended practices" of the American Oil Chemists Society, $5^{\text {th }}$ edition, Champaign, IL.

Badger W.L., Banchero J.T. 1955. Introduction to Chemical Engineering, McGraw-Hill, Inc., New York.
Berardi L.C., Martinez W.F., Fernandez E. 1969. Cottonseed protein isolates: two step extraction procedure. J. Food Technol. 23, 27.

Fan T.Y., Sosulski, F.W. 1974. Isolation of protein from legume flours. Canadian Institute Food Science Technology J. 7, 256.

Lyman C.M., Chang W.I., Couch I.R. 1953. Evaluation of protein quality in cottonseed meals by chick growth and by chemical Index method. J. Nutrition 49, 679-690.

Mecabe W.L., Smith J.C., Harriott, P. 1993. Unit Operations of Chemical Engineering, $5^{\text {th }}$ ed., McGraw-Hill, Inc., New York.

Taha F.S., Abbasy M., EL- Nochkrashy A.S., Shoeb, Z.E. 1981. Countercurrent extraction - isoelectric precipitation of sunflower seed protein isolates. J. Sci Food Agric. 32,166-174.

Taha F.S., Mohamed S.S., EL-Nochrashy, A.S. 1986. Light colored protein for nutritious beverages. Grasas $y$ Aceites 37, 8-13.

Taha F.S., Fahmy M., Sadek, M.A. 1987. Low-phytate protein concentrate and isolate from sesame seed. $J$. Agric. Food Chem. 35, 289-292. 